INSIGHTS INTO REGIONAL DEVELOPMENT

ISSN 2669-0195 (online) http://jssidoi.org/IRD/

2020 Volume 2 Number 2 (June)

http://doi.org/10.9770/IRD.2020.2.2(4)

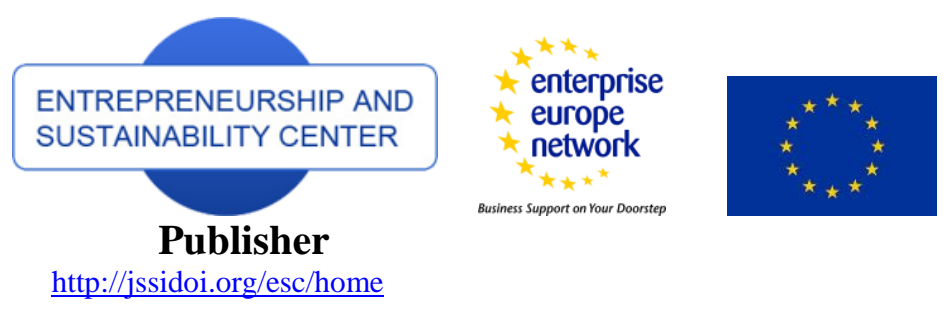

\title{
EMPIRICAL INTERPRETATION AND MEASUREMENT OF THE PRODUCTIVITY AND EFFICIENCY OF REGIONS: THE CASE OF LATVIA
}

\author{
Evgeniy Korshenkov ${ }^{1}$, Sergey Ignatyev ${ }^{2}$ \\ ${ }^{1,2}$ Baltic International Academy, Darzu street 17, Rezekne, Latvia \\ E-mails:" jevgenij.korshenkov@gmail.com; ${ }^{2}$ igs@bk.ru
}

Received 10 December 2019; accepted 20 March 2020; published 30 June 2020

\begin{abstract}
The main concepts of this study are productivity and efficiency, which are very relevant for Latvia and are reflected both in the latest scientific publications, dissertation researches and analytical reviews of the Latvian ministries and representatives of the European Commission in Latvia, as well as in expert reports published in the press. The objective of this article is empirical interpretation and search of the most corresponding to the terminological background method of measuring of the productivity and efficiency of regions, based on a specific example of the regions of Latvia. The results of the previous authors' research showed that the productivity of region is defined as it's ability to create as many as possible goods or services per unit of time, while the efficiency is the pure economical term that takes into account the amount of the factors of production utilizied in the production process. Productivity / efficiency of a region is not only the sum of the productivity / efficiency of economical units functioning in this region, as contains a certain "delta" - synergy effect (for factors of production), agglomeration effect (for enterprises) or concentration effect (for industries). Always economically backward Latvia's region (Latgale region) is not with the lowest productivity calculated by the GDP per $1 \mathrm{~km}^{2}$ of a region's territory - by this indicator less successful in Latvia is Vidzeme region. But by the earnings index, calculated taking into account the sectoral structure of employment in a region, exactly the Latgale region as usually occupies the last place in Latvia, and the Riga region - the first one. To calculate the efficiency of Latvia's regions, the authors relied on neoclassical growth models, which take into account the main classical factors of production - labor, land, capital. By the efficiency in Latvia the Riga region leads expectantly, almost 2 times exceeding the efficiency of Pieriga region, and more than 3 times, - the efficiency of Latgale region. But lowest efficiency in Latvia is not in the Latgale region, but once more in Vidzeme region.
\end{abstract}

Keywords: production process; factors of production; productivity; efficiency; regions; Latvia

Reference to this paper should be made as follows: Korshenkov, E., Ignatyev, S. 2020. Empirical interpretation and measurement of the productivity and efficiency of regions: The case of Latvia. Insights into Regional Development, 2(2), 549561. https://doi.org/10.9770/IRD.2020.2.2(4)

JEL Classifications: C67, D24, E23

\section{Introduction}

The basic concepts of this study are productivity and efficiency, which are very relevant for Latvia and are reflected in the latest scientific publications (Baranova et al., 2019; Stepinya, 2019; Shteinbuka, 2019), dissertation researches (Krasnopyorovs, 2012) and analytical reviews of ministries of Latvia (Asheradens, 2017; 


\section{INSIGHTS INTO REGIONAL DEVELOPMENT}

ISSN 2669-0195 (online) http://jssidoi.org/jesi/

2020 Volume 2 Number 2 (June)

http://doi.org/10.9770/IRD.2020.2.2(4)

Bremshmits, 2019) and representatives of the European Commission in Latvia (Zemitis, 2019), as well as in expert reports published in the press (Helmane, 2017; Jekabsone, Skribane, 2018).

The American economist, the author of the "new economic geography" theories, P. Krugman, back in the early 1990 s, argued that the only way to improve living standards in the long run is to increase productivity and efficiency (Krugman, 1991a, 1991b, 1997), which is especially relevant for those countries and regions which in their economic development are at the so-called efficiency-driven stage, since it is at this stage that efficiency is the main engine of economical growth (Sala-i-Martín et al., 2016). In Latvia, such regions are Zemgale, Vidzeme, and Latgale (Zeibote, 2018).

An analysis of the scientific literature (Shteinbuka, 2019) made by the authors showed that in Latvia's economic science there is no systemic understanding of the differences between the terms and concepts "productivity" and "efficiency" as well as their equivalent translation into Russian and Latvian, which, according to the authors, is a serious obstacle to implementation high-quality studies of the problem of increasing productivity and efficiency in the regional economics of Latvia (Korshenkov et al., 2019).

Based on the analysis of linguistic and economic dictionaries (Brockhaus, Efron, 1909; Taube, 1966; Zhdanova, 1995; Zenovich, 1998; Azriliyan, 2002; Egorova, 2014), as well as scientific publications (Drucker, 1977; Daft, 2009; Borisenko, 2014; Stack, 2016), the authors found that productivity is defined as the ability (of a factor of production, of an enterprise, of an industry, of a region) to create as much product as possible per unit of time and is put "at the forefront" - without taking into account the efficiency of the production process - in a planned economy. In its turn, efficiency is a pure economical term that takes into account the amount of resources (factors of production) utilizied in the production process (Korshenkov et al., 2019).

In the framework of this article, the authors will try to answer two research questions: 1) how the productivity and efficiency of factors of production, enterprises and industries are interrelated with the productivity and efficiency of regions?

2) how the productivity and efficiency of regions could be measured?

To achieve the objective of this study, all the studied territories — both countries and their inner regions - are taken as regions, since in economic science a region is a territory with a specific economy (Granberg, 2004; Volkov, 2004; Boronenko, 2007), and by this definition a country can also be called a region. Therefore, the objective of this article is empirical interpretation and search of the most corresponding to the terminological background method of measuring of the productivity and efficiency of regions, illustrated by the particular example of the regions of Latvia: Riga, Pieriga (the territory around Riga), Kurzeme, Zemgale, Vidzeme, and Latgale.

\section{What is the subject of productivity and efficiency?}

In this Section of the article, it is necessary to answer the research question on how the productivity and efficiency of factors of production, enterprises and industries interrelate with the productivity and efficiency of regions. In other words: when we study and measure productivity and efficiency, what is the subject, i.e. "the productivity of what" and "the efficiency of what" we are investigating? Answering this question, the authors will constantly keep in mind that they are primarily interested in the productivity and efficiency of regions, which should also be distinguished from the productivity and efficiency of - as an example - labor as a factor of production (or, for example, capital) in regions, i.e. regional productivity of labor (or, for example, capital) as a factor of production. I. Borisenko in his study of the modern concept of increasing the efficiency of entrepreneurship, concludes that 


\section{INSIGHTS INTO REGIONAL DEVELOPMENT}

ISSN 2669-0195 (online) http://jssidoi.org/jesi/

2020 Volume 2 Number 2 (June)

http://doi.org/10.9770/IRD.2020.2.2(4)

the productivity and efficiency of a region and the productivity and efficiency of labor (or any other factor of production or their combination) are general and particular, i.e. productivity and efficiency, for example, of labor as a factor of production is a component of the productivity and efficiency of a region (Borisenko, 2014).

Thus, the productivity and efficiency of a region is the result of the "work" of all factors of production available in the region and all enterprises or industries operating in the region, i.e. the result of the functioning of the region's economy. In its turn, the productivity and efficiency of each individual factor of production - labor, capital, land, information, etc. - will be called already "labor productivity" or "capital efficiency", or "labor and capital productivity or efficiency" (or any other combination of production factors) in a region, but not the productivity and efficiency of a region. So, the authors agree with I. Borisenko that it is incorrect to similize, for example, "productivity and efficiency of a region" and "labor productivity and efficiency in a region" (Borisenko, 2014), since the first includes not only the productivity and efficiency of labor in a particular region, but also the productivity and efficiency of all other factors of production plus the synergy effect, the importance of which in modern economic science has been recognized and updated in numerous and already classical works of M. Porter (Porter, 1980, 1981, 1985, 1987, 1990, 1991, 1996). Latvian researchers also note that, for example, the contribution of technological progress into increasing productivity and efficiency is greater where there are skilled people with high level of knowledge who are able to both apply new technologies and develop them (Stepinya, 2019), i.e. the synergy effect is manifested when the factor of new technologies is combined with the factor of high-quality human capital. The economic theory of agglomeration - beginning with the classic works of A. Marshall with his famous "industry secrets are in the air" (Marshall, 1890) - emphasizes, in turn, the significance of the agglomeration effect, which is especially manifesting in economic clusters and industrial areas (Boronenko, 2009; Radeva, 2014; Zeibote, 2018). The agglomeration effect is the reason that the productivity and efficiency of regions is not only a simple sum of the productivity and efficiency of enterprises operating in a particular region, but also contains a certain "delta" - a derivative of the degree of agglomeration of enterprises in a region (Ullman, 1958; Fujita et al., 1999; Nechet et al., 2012).

In its turn, the sectoral structure of a region's economy also has its own "delta" - the effect of the concentration of economic industries in a region, which has been studied just in few number of publications of Latvian economic researchers (Boronenko, Zeibote, 2010; Zeibote, 2018), without "going out" to the specialization of regions, based on the increased concentration of one or another industry (or some industries) in a particular region (Bogetic, Sanogo, 2005). (See Figure 1).

Productivity / efficiency of a region

\begin{tabular}{|c|c|c|}
\hline Synergy effect & $\begin{array}{c}\text { Agglomeration } \\
\text { effect }\end{array}$ & $\begin{array}{c}\text { Concentration } \\
\text { effect }\end{array}$ \\
\hline $\begin{array}{c}\text { Sum of } \\
\text { productivity / } \\
\text { efficiency of } \\
\text { factors of } \\
\text { production of } \\
\text { a region }\end{array}$ & $\begin{array}{l}\text { The sum of } \\
\text { productivity / } \\
\text { efficiency of } \\
\text { enterprises of a } \\
\text { region }\end{array}$ & $\begin{array}{l}\text { The sum of the } \\
\text { productivity / } \\
\text { efficiency of } \\
\text { industries of a } \\
\text { region }\end{array}$ \\
\hline
\end{tabular}

Fig. 1. The ratio of productivity / efficiency* of regions and factors of production / enterprises / industries

\footnotetext{
* The productivity and efficiency of regions in this figure are presented as two parallel processes with the same methodological approach to the ratio of general and particular

Source: created by the authors based on Marshall, 1890; Ullman, 1958; Porter, 1980, 1996; Fujita et al., 1999; Boronenko, 2009; Nechet et al., 2012; Borisenko, 2014; Radeva, 2014; Zeibote, 2018; Stepinya, 2019.
} 


\section{INSIGHTS INTO REGIONAL DEVELOPMENT}

ISSN 2669-0195 (online) http://jssidoi.org/jesi/

2020 Volume 2 Number 2 (June)

http://doi.org/10.9770/IRD.2020.2.2(4)

Thus, the productivity / efficiency of regions includes, on the one hand, the sum of the productivity / efficiency of the region's factors of production plus the synergy effect from their interaction, on the other hand, the sum of the productivity / efficiency of the region's enterprises plus the effect from the degree of their agglomeration in a region, and third, the sum of the productivity / efficiency of industries plus the effect from the degree of their concentration in a region - similar to how GDP can be calculated in three ways: by income, expenses and value added (Samuelson, Nordhaus, 2010).

\section{How to measure the productivity and efficiency of regions?}

Based on the author's systemic analysis of the main terms and concepts of this study (Korshenkov et al., 2019), the productivity of regions is empirically interpreted as the ability of regional economies to create as many products as possible per time unit - output per unit of time, i.e. "do many things" (Stack, 2016), without taking into account the resources used for this. Thus, when measuring the productivity of regions, the proposed tools should include a time indicator (Brockhaus, Efron, 1909; Stack, 2016), but not refer to the quantity of factors of production spent - labor, capital, and others, because the efficiency refers to the amount and costs of the used resources.

Since in the research practice of economic science the unit of time when measuring productivity is traditionally considered an hour, month, quarter, half a year or an year (Borisenko, 2014), in order to analyze how the productivity of regions is measured in economic studies, it is necessary to collect all possible measuring tools, which show how many goods and services are produced in a region for at least at one of the aforementioned units of time. But here there is one more problem - the regions differ in area and in the number of population, therefore it is also necessary to understand how we will compare the productivity of regions with each other, as well as the performance of the same region in dynamics, i.e. in relation to itself.

The productivity of regions in the scientific literature is usually measured using gross domestic product (GDP), i.e. the total cost of goods and services produced per year per capita (which takes into account the difference between regions in terms of population) in a given region (Barro, Sala-i-Martin, 1992, 2004; H.M. Treasury, 2001; Rice, Venables, 2004a, 2004b). Although the authors, following many scientific studies, are inclined to consider GDP per capita as an indicator of economic performance of regions (Rice, Venables, 2004a, 2004b; New Zealand Institute of Economic Research, 2014; Simpson, 2014; Stankevics, 2014; Stankevics et al., 2014; Boronenko et al., 2014), but not an indicator of its productivity, since not every "per capita" is involved in the production process, but each of them consumes its results, therefore, the GDP per capita indicator is important for measuring the economic situation in a region.

In many economic studies, productivity of regions is measured using GDP per working hour (Evans, Siegel, 1942; Asheradens, 2017), GDP per worker (which can already be attributed to the measurement of efficiency) (Abel et al., 2010; Baranova et al., 2019) or GDP per square kilometer of territory (which takes into account the difference between regions in terms of area) (International Monetary Fund, 2019). R. Rice and A. Venables suggest to use also the earnings index as a tool of measuring the productivity of regions, calculated taking into account the sectoral structure of employment in a region (Rice, Venables, 2004a, 2004b). The Central Statistical Bureau of Latvia does not have information about GDP per working hour, in turn, GDP per capita or per employee, as mentioned above, is not suitable for measuring productivity of regions - thus, for practical implementation of study, the object of which are the regions of Latvia, the authors use the indicators that are presented in the Table 1 . 
INSIGHTS INTO REGIONAL DEVELOPMENT

ISSN 2669-0195 (online) http://jssidoi.org/jesi/

2020 Volume 2 Number 2 (June)

http://doi.org/10.9770/IRD.2020.2.2(4)

Table 1. Values of indicators suitable for measuring productivity of Latvia's regions, 2016*

\begin{tabular}{|c|c|c|}
\hline Regions of Latvia & $\begin{array}{c}\text { GDP per } 1 \mathrm{~km}^{2} \text { of territory } \\
\text { (in current prices), thousands EUR }\end{array}$ & $\begin{array}{c}\text { Earnings index } * * \\
\text { (taking into account the sectoral structure } \\
\text { of employment) }\end{array}$ \\
\hline Riga region & 44407.4 & 9.54 \\
\hline Pieriga region & 376.8 & 6.98 \\
\hline Vidzeme region & 106.9 & 7.21 \\
\hline Kurzeme region & 173.7 & 7.33 \\
\hline Zemgale region & 178.0 & 5.91 \\
\hline Latgale region & 122.4 & 8.82 \\
\hline LATVIA as a whole & 387.7 & \\
\hline * the last year for which, at the time of writing, the Latvian official statistics had data on GDP in the regions of Latvia \\
calculated by adding the average monthly gross earnings in various sectors of the region's economy, multiplied by the share of
\end{tabular}

The authors believe that the annual GDP per $1 \mathrm{~km}^{2}$ of the region's territory and the earnings index in the region are those indicators that empirically characterize and can serve to measure the productivity of regions. It is interesting that in relation to the regions of Latvia, Latgale region, which is traditionally lagging behind in economic indicators, is not the lowest productive in terms of GDP per $1 \mathrm{~km}^{2}$ of territory - according to this indicator, Vidzeme region is the most disadvantageous in Latvia.

The Table 2 data on the area of the regions of Latvia and the population density give a reason to assume - and this is confirmed by the results of the correlation analysis - that the level of productivity of regions depends very much on these indicators: the region's productivity is higher, if it's territory is smaller and the higher the density population in this territory (see Table 2), which, in turn, confirms the authors' thesis that the efficiency of regions include the effects of synergy, agglomeration and concentration (see Figure 1) and these effects are most noticeable in small regions with a relatively high population density.

Table 2. GDP per $1 \mathrm{~km}^{2}$ of the territory of the regions of Latvia

and its dependence on the area and population density in these regions, 2016

\begin{tabular}{|c|c|c|c|}
\hline Regions of Latvia & $\begin{array}{c}\text { GDP per } 1 \mathrm{~km}^{2} \text { of territory } \\
\text { (in current prices), thousands } \\
\text { EUR }\end{array}$ & The area of the region, $\mathrm{km}^{2}$ & $\begin{array}{l}\text { Population density per } 1 \mathrm{~km}^{2} \\
\text { of territory, absolute values }\end{array}$ \\
\hline Riga region & 44407.4 & 304 & 2104 \\
\hline Pieriga region & 376.8 & 10135 & 36 \\
\hline Vidzeme region & 106.9 & 15245 & 13 \\
\hline Kurzeme region & 173.7 & 13607 & 18 \\
\hline Zemgale region & 178.0 & 10732 & 22 \\
\hline Latgale region & 122.4 & 14550 & 19 \\
\hline LATVIA as a whole & 387.7 & 64573 & 30 \\
\hline \multicolumn{2}{|c|}{$\begin{array}{l}\text { The interdependence between the productivity of a region and its } \\
\text { area / population density, the Pearson`s correlation coefficient, } \\
\qquad n=6 \text { regions }\end{array}$} & $-0.930, r=0.000$ & $1.000, r=0.000$ \\
\hline
\end{tabular}

Source: calculated by the authors according to Central Statistical Bureau of Latvia, 2019a, 2019b.

As already noted in the Introduction to this article, productivity was emphasized in a planned economy. It is also believed that the cult of productivity "caused great damage to nature and a lot of suffering to society" (Bevins, 2017). The authors argue that the disproportionate - in comparison to other regions - productivity growth of the relatively small area of the Riga region in Latvia was one of the reasons for the outflow of economic activity from 
INSIGHTS INTO REGIONAL DEVELOPMENT

ISSN 2669-0195 (online) http://jssidoi.org/jesi/

2020 Volume 2 Number 2 (June)

http://doi.org/10.9770/IRD.2020.2.2(4)

Riga to Pieriga region, which began in the first decade of the $21^{\text {st }}$ century (Boronenko, 2009; SelivanovaFyodorova et al., 2019).

As for the second indicator of the productivity of regions identified by the authors basing on the work of P. Rice and A. Venables (Rice, Venables, 2004a, 2004b), the earnings index (calculated taking into account the sectoral structure of employment, see Tables 1 and 3), then the possibility of its application in the study of the Latvian economy is confirmed by the results of a study of the World Economic Forum, namely, data on the indicator "pay and productivity", which measures the adequacy of earnings to the labor productivity and according to which Latvia in 2016 took $49^{\text {th }}$ place out of 138 with 4.3 points out of 7 possible (World Economic Forum, 2016), and in 2018 - already $46^{\text {th }}$ place out of 140 with 4.4 points (World Economic Forum, 2018) - i.e., we can consider that in Latvia the indicator of earnings matches to the labor productivity. And according to this indicator, it is Latgale region that habitually takes the last place in Latvia, and the Riga region - the first one (see Table 1).

Table 3 presents the data on which the earnings index in the regions of Latvia was calculated and from the analysis of which we can conclude that the problems and challenges related to the productivity of regions of Latvia are not the same in Riga and Pieriga regions in comparison with all other regions of Latvia. So, if in Riga and Pieriga regions (and, as it may seem without additional analysis, in Latvia as a whole), the main "growth point" of productivity of the region is a decrease of employment in the lowest-performing industries of the economy - wholesale and retail trade, car and motorcycle repair; hotel industry and catering services - or, correspondingly, increasing the productivity of these industries (see Table 3), then in other regions of Latvia there is no such a problem - nor in one of the peripheral regions of Latvia is not observed the largest share of people employed in these lowest-performing sectors of economy (see Table 3), but at the same time, the productivity of the peripheral regions themselves, measured using the earnings index, is still lower than in Riga and Pieriga regions (see Table 1). Perhaps the reason is that those industries - namely: transport and storage; information and communication services, which are the most productive in Riga and Pieriga regions (and, as it may again seem without additional analysis, in Latvia as a whole), are not such in all other regions of Latvia (see Table 3).

In calculations of the earnings index these two sectors - transport and storage; information and communication services - are combined by the authors according not for their own free will, but basing on the capabilities of the Latvian official statistics, which have data on the number of people employed in the regions for only these two sectors together, although there are some data on earnings that show, firstly, that the average monthly gross earnings in Latvia in the information and communication services industry is much higher than in the transport and storage industry (but this does not refer to all regions of Latvia), and secondly, this difference is significant only in Riga and Pieriga regions (Central Statistical Bureau of Latvia, 2019c):

- in Latvia as a whole for 2016: transport and storage - 870 EUR;

information and communication services - 1364 EUR;

- in Riga region: transport and storage - 924 EUR;

information and communication services - 1440 EUR;

- in Pieriga region: transport and storage - 869 EUR;

information and communication services - 1255 EUR;

- in Vidzeme region: transport and storage - 690 EUR;

information and communication services - 655 EUR;

- in Kurzeme region: transport and storage - 928 EUR;

information and communication services - 727 EUR;

- in Zemgale region: transport and storage - 620 EUR;

information and communication services - 650 EUR;

- in Latgale region: transport and storage - 551 EUR;

information and communication services -610 EUR. 
INSIGHTS INTO REGIONAL DEVELOPMENT

ISSN 2669-0195 (online) http://jssidoi.org/jesi/

2020 Volume 2 Number 2 (June)

http://doi.org/10.9770/IRD.2020.2.2(4)

Table 3. The average monthly gross earnings in the industries

in relation to the sectoral structure of employment in the regions of Latvia, 2016

\begin{tabular}{|c|c|c|c|c|c|c|c|c|c|c|}
\hline Indicators and regions & $\mathrm{A}$ & B-E & $\mathrm{F}$ & G,I & $\mathrm{H}, \mathrm{J}$ & $\mathrm{K}-\mathrm{N}$ & $\mathrm{O}$ & $\mathrm{P}$ & $\mathrm{Q}$ & R-U \\
\hline \multicolumn{11}{|c|}{ Riga region } \\
\hline $\begin{array}{l}\text { Average monthly gross earnings } \\
\text { in the industry, EUR }\end{array}$ & 1222 & 993 & 884 & 742 & 1182 & 1130 & 1125 & 780 & 874 & 794 \\
\hline $\begin{array}{l}\text { Share of people employed in the industry, } \\
\% \text { of the total number of employees }\end{array}$ & 0.0 & 12.9 & 6.7 & 20.5 & 14.9 & 17.2 & 6.8 & 8.4 & 5.7 & 6.6 \\
\hline \multicolumn{11}{|c|}{ Pieriga region } \\
\hline $\begin{array}{l}\text { Average monthly gross earnings } \\
\text { in the industry, EUR }\end{array}$ & 706 & 870 & 808 & 665 & 1062 & 957 & 1050 & 740 & 739 & 709 \\
\hline $\begin{array}{c}\text { Share of people employed in the industry, } \\
\% \text { of the total number of employees }\end{array}$ & 7.0 & 17.1 & 8.6 & 17.9 & 10.1 & 11.7 & 7.0 & 8.6 & 5.8 & 5.2 \\
\hline \multicolumn{11}{|c|}{ Vidzeme region } \\
\hline $\begin{array}{l}\text { Average monthly gross earnings } \\
\text { in the industry, EUR }\end{array}$ & 740 & 789 & 690 & 521 & 673 & 725 & 836 & 631 & 719 & 607 \\
\hline $\begin{array}{l}\text { Share of people employed in the industry, } \\
\% \text { of the total number of employees }\end{array}$ & 16.7 & 19.9 & 6.9 & 13.2 & 9.1 & 6.6 & 6.0 & 11.4 & 6.3 & 4.1 \\
\hline \multicolumn{11}{|c|}{ Kurzeme region } \\
\hline $\begin{array}{l}\text { Average monthly gross earnings } \\
\text { in the industry, EUR }\end{array}$ & 664 & 796 & 921 & 518 & 828 & 710 & 849 & 642 & 751 & 583 \\
\hline $\begin{array}{c}\text { Share of people employed in the industry, } \\
\% \text { of the total number of employees }\end{array}$ & 13.1 & 20.4 & 9.3 & 15.5 & 10.5 & 7.2 & 6.1 & 8.0 & 4.9 & 4.8 \\
\hline \multicolumn{11}{|c|}{ Zemgale region } \\
\hline $\begin{array}{l}\text { Average monthly gross earnings } \\
\text { in the industry, EUR }\end{array}$ & 863 & 893 & 731 & 553 & 635 & 656 & 883 & 647 & 715 & 622 \\
\hline $\begin{array}{c}\text { Share of people employed in the industry, } \\
\% \text { of the total number of employees }\end{array}$ & 12.5 & 18.7 & 8.6 & 16.6 & 9.4 & 6.9 & 8.3 & 9.2 & 5.5 & 4.3 \\
\hline \multicolumn{11}{|c|}{ Latgale region } \\
\hline $\begin{array}{l}\text { Average monthly gross earnings } \\
\text { in the industry, EUR }\end{array}$ & 608 & 628 & 577 & 437 & 581 & 567 & 712 & 611 & 676 & 513 \\
\hline $\begin{array}{c}\text { Share of people employed in the industry, } \\
\% \text { of the total number of employees }\end{array}$ & 12.8 & 17.1 & 4.8 & 13.1 & 13.1 & 6.9 & 7.9 & 11.4 & 8.5 & 4.3 \\
\hline \multicolumn{11}{|c|}{ LATVIA as a whole } \\
\hline $\begin{array}{l}\text { Average monthly gross salary } \\
\text { in the industry, euro }\end{array}$ & 820 & 947 & 828 & 677 & 1117 & 1078 & 1071 & 703 & 799 & 722 \\
\hline $\begin{array}{c}\text { Share of people employed in the industry, } \\
\% \text { of the total number of employees }\end{array}$ & 7.7 & 16.7 & 7.4 & 17.3 & 12.0 & 11.4 & 7.0 & 9.1 & 6.0 & 5.3 \\
\hline
\end{tabular}

Source: calculated by the authors according to Central Statistical Bureau of Latvia, 2019c, 2019d.

A - agriculture, forestry and fisheries

B-E - mining and quarrying; manufacturing industry; electricity, gas, heat and air conditioning

$\mathrm{F}$ - construction

G, I - wholesale and retail trade, car and motorcycle repair; hotel facilities and catering services

$\mathrm{H}, \mathrm{J}$ - transport and storage; information and communication services

$\mathrm{K}-\mathrm{N}$ - financial and insurance services; real estate operations; professional, scientific and technical services;

administrative and service activities

$\mathrm{O}$ - public administration and protection; compulsory social insurance

$\mathrm{P}$ - education

$\mathrm{Q}$ - health and social services

$\mathrm{R}$ - art, entertainment and leisure; other services

As already noted in the Introduction to this article, efficiency - in contrast to productivity - is related to the result of the production process, i.e. created goods and services, with the amount of factors of production used within the production process. The following Table shows the indicators suitable for measuring efficiency of regions and calculated in relation to the regions of Latvia. 
INSIGHTS INTO REGIONAL DEVELOPMENT

ISSN 2669-0195 (online) http://jssidoi.org/jesi/

2020 Volume 2 Number 2 (June)

http://doi.org/10.9770/IRD.2020.2.2(4)

Table 4. Values of indicators suitable for measuring efficiency of regions, in the regions of Latvia, 2016

\begin{tabular}{|c|c|c|c|c|c|c|c|}
\hline \multirow{2}{*}{$\begin{array}{l}\text { Factors of production } \\
\text { in the region }\end{array}$} & \multicolumn{6}{|c|}{ Regions of Latvia } & \multirow{2}{*}{$\begin{array}{l}\text { LATVIA } \\
\text { as a whole }\end{array}$} \\
\hline & $\begin{array}{l}\text { Riga } \\
\text { region }\end{array}$ & $\begin{array}{l}\text { Pieriga } \\
\text { region }\end{array}$ & $\begin{array}{l}\text { Vidzeme } \\
\text { region }\end{array}$ & $\begin{array}{c}\text { Kurzeme } \\
\text { region }\end{array}$ & $\begin{array}{l}\text { Zemgale } \\
\text { region }\end{array}$ & $\begin{array}{l}\text { Latgale } \\
\text { region }\end{array}$ & \\
\hline Area (land) & 0.005 & 0.157 & 0.236 & 0.211 & 0.166 & 0.225 & 1.000 \\
\hline $\begin{array}{c}\text { Number of employed } \\
\text { (labor) }\end{array}$ & 0.348 & 0.198 & 0.095 & 0.122 & 0.116 & 0.122 & 1.000 \\
\hline $\begin{array}{c}\text { Non-financial } \\
\text { investments (capital) }\end{array}$ & 0.595 & 0.177 & 0.056 & 0.065 & 0.065 & 0.042 & 1.000 \\
\hline $\begin{array}{c}\text { The relative amount of } \\
\text { the main factors of } \\
\text { production in the } \\
\text { region }\end{array}$ & 0.948 & 0.532 & 0.387 & 0.398 & 0.347 & 0.389 & 3.000 \\
\hline $\begin{array}{l}\text { Relative share of GDP } \\
\text { produced in the region }\end{array}$ & 0.539 & 0.153 & 0.065 & 0.094 & 0.076 & 0.071 & 1.000 \\
\hline $\begin{array}{c}\text { Efficiency } \\
\text { of the region }\end{array}$ & 0.57 & 0.29 & 0.17 & 0.24 & 0.22 & 0.18 & 0.33 \\
\hline
\end{tabular}

*calculated by dividing the relative amount of the main factors of production in the region by the relative share of GDP produced in this region; the calculation method implies a mandatory comparison of results between regions, while the efficiency indicator of one region without comparison with others is not informative

Note: Efficiency of the region: The concept of energoinformation is also used in modern economic science, which combines the characteristics of knowledge and the efforts necessary to obtain and use this knowledge efficiently (Kurakov, 2017)

Source: elaborated by the authors according to Central Statistical Bureau of Latvia, 2019a, 2019b, 2019d, 2019e.

To measure the efficiency of Latvia's regions, the authors relied on neoclassical growth models (Solow, 1956; Romer, 1989a, 1989b; Mankiw et al., 1992), which take into account the main classical factors of production labor, land, capital, although the authors also recognize the importance of other factors of production that have been identified in the modern economic theory - for example, such as entrepreneurial talent (Cusolito, Maloney, 2018; INSEAD et al., 2019), information and knowledge (Berczi, 1981; Neef, 2003; Cocalia, 2015), technology (Brynjolfsson, Hitt, 1995) and others.

The results of the authors' calculations, presented in Table 4, show that Riga region is expected to lead in terms of efficiency in Latvia, being almost 2 times more efficient than Pieriga region, and approximately 3 times more efficient than Latgale region. But - just as in the case of the productivity of regions, measured by GDP per $1 \mathrm{~km}^{2}$ of the region's territory, the most low-efficient region in Latvia is not the Latgale, but Vidzeme region again (see Table 4).

As for the main sources of the efficiency of Latvia's regions, in the case of Riga region, th efficiency is characterized by the highest return on capital and labor (1.7/1), concentrated on 5\% of the country's territory, and in case of Pieriga region this ratio is already changing towards a slight dominance of labor in relation to capital (in the ratio $1.1 / 1$ ) without a strong territorial concentration (although it is quite possible that an additional study of the territorial distribution of labor and capital in the Pieriga region would show the presence of their territorial agglomeration, intensifying as one approaches Riga). In all other regions of Latvia, a certain - relatively low level of efficiency is achieved mainly due to the relative vastness of the area in which economical activity is conducted (see Table 4). 


\section{Conclusions}

1. Based on the analysis of linguistic and economic dictionaries, as well as scientific publications, the authors found that productivity is defined as the ability (of a factor of production, of an enterprise, of an industry, of a region) to create as much product as possible per unit of time and is put "at the forefront" without taking into account the efficiency of the production process - in a planned economy. In its turn, efficiency is a pure economical term that takes into account the amount of resources (factors of production) utilizied in the production process.

2. The productivity / efficiency of a region and the productivity / efficiency of a factor of production, enterprises or industries represent a general and particular concept, while the general is not only a simple sum of the productivity / efficiency of the terms functioning in a particular region, since it also contains a certain "delta" - the synergy effect (for factors of production), the agglomeration effect (for enterprises) or the concentration effect (for industries).

3. The authors argue that the annual GDP per $1 \mathrm{~km}^{2}$ of the region's territory and the earnings index calculated taking into account the sectoral structure of employment in a region are those indicators that empirically characterize and can serve to measure the productivity of regions. The Latgale region of Latvia, traditionally lagging behind in economic indicators, is not the lowest productive in terms of GDP per $1 \mathrm{~km}^{2}$ of territory - according to this indicator, Vidzeme region is the most disadvantaged in Latvia. As regards to the earnings index, it is precisely the Latgale region that is ranked last in Latvia by this indicator, and the Riga region is the first.

4. To investigate the efficiency of Latvia's regions, the authors relied on neoclassical growth models, which take into account the main classical factors of production - labor, land, capital. The results of the authors' calculations show that Riga region is expected to lead in Latvia in terms of the efficiency, which is almost 2 times higher than the efficiency of Pieriga region, and approximately 3 times higher than the efficiency of Latgale region. However, Latgale region turned out to be the most low-efficient in Latvia, but again as in the case of productivity measured by the GDP per $1 \mathrm{~km}^{2}$ of territory - Vidzeme region is lowerefficient in Latvia.

5. The main sources of the efficiency in Riga region are capital and labor (1.7 / 1 ratio), concentrated on 5\% of the territory of Latvia, and in case of Pieriga region this ratio is already changing towards a slight dominance of labor relative to capital $-1.1 / 1$, without a strong territorial concentration. In all other regions of Latvia, a certain - relatively low - level of efficiency is achieved mainly due to the relatively large area of their territory.

\section{References}

Abel, J.; Dey, I.; Gabe, T. 2010. Productivity and the density of human capital, Federal Reserve Bank of New York Staff Reports 440. Retrieved from https://www.newyorkfed.org/medialibrary/media/research/staff reports/sr440.pdf

Asheradens, A. 2017. Produktivitāte Latvijā: tendences, izaicinājumi un politika. [Efficiency in Latvia: tendencies, challenges and policy]. Riga, Latvia: Ministry of Economy of the Republic of Latvia. Retrieved from https://esmaja.lv/sites/default/files/2019-03/a_aseradens produktivitate_latvija__tendences_izaicinajumi_politika_20170602.pdf

Azriliyan, А. (Ed.). 2002. Большой экономический словарь. [Big Economic Dictionary]. Moscow, Russia: Institute of the New Economy. 


\section{INSIGHTS INTO REGIONAL DEVELOPMENT}

ISSN 2669-0195 (online) http://jssidoi.org/jesi/

2020 Volume 2 Number 2 (June)

http://doi.org/10.9770/IRD.2020.2.2(4)

Baranova, D.; Baranovs, O.; Berzinsh, G.; Skribane, I. 2019. Produktivitāte Latvijā: tendences, izaicinājumi, politika [Efficiency in Latvia: tendencies, challenges and policy], in Shteinbuka I. (Ed.). Produktivitātes celšana: tendences un nākotnes izaicinājumi. [Increase of Efficiency: Tendencies and Future Challenges]. Riga, Latvia: Academic Publishing House of the University of Latvia, 43-146.

Barro, R.; Sala-i-Martin, X. 1992. Convergence, Journal of Political Economy 2(100): 223-251. https://doi.org/10.1086/261816

Barro, R.; Sala-i-Martin, X. 2004. Economic Growth. 2nd edition. London, UK: MIT Press.

Berczi, A. 1981. Information as a factor of production, Business Economics 1(16): 14-20.

Bevins, V. 2017. Productiviy is Dangerous. Retrieved from https://theoutline.com/post/2595/productivity-is-dangerous

Bogetic, Z.; Sanogo, I. 2005. Infrastructure, productivity and urban dynamics in Cote d'Ivoire: an empirical analysis and policy implications, Africa Region Working Paper Series 86. Washington, DC: World Bank. Retrieved from

http://documents.worldbank.org/curated/en/107141468247819021/pdf/342470PAPER0CI0Urban0dynamics0AFRwp86.pdf

Borisenko, I. 2014. Современная концепция повыщения производительности предпринимательства [The modern conception of the increasing of entrepreneurship's productivity], Организатор производства [Organizer of Production] 4(63): 5-15.

Boronenko, V. 2007. Klasteru pieeja reǵionu attīstībai zināšanu ekonomikas apstākḷos. [Cluster Approach for the Development of Regions in Conditions of the Knowledge Economy]. Daugavpils, Latvia: Academic Publishing House "Saule" of the Daugavpils University.

Boronenko, V. 2009. Klasteru loma reǵionu konkurētspējas paaugstināšanā. [The Role of Clusters in the Development of Regional Competitiveness]. Doctoral Thesis. Yelgava, Latvia: Latvia University of Agriculture.

Boronenko, V.; Mensikovs, V.; Lavrinenko, O. 2014. The impact of EU accession on the economic performance of the countries' internal (NUTS 3) regions, Journal of Economics and Business (Proceedings of Rijeka Faculty of Economics) 2(32): 313-341.

Boronenko, V.; Zeibote, Z. 2010. Специфика региональной концентрации рабочей силы в экономике Латвии, Social Sciences Bulletin 2(11): 77-96.

Bremsnmits, R. 2019. Reǵionālā ekonomika, reǵionu un pašvaldību loma tajā. [Regional Economics, the Role of Regions and Municipalities]. Riga, Latvia: Ministry of Environmental Protection and Regional Development of the Republic of Latvia.

Brockhaus, F.; Efron, I. 1909. Малый энциклопедический словарь. [Small Encyclopedic Dictionary]. Saint-Peterbourg, Russia: Brockhaus-Efron.

Brynjolfsson, E.; Hitt, L. 1995. Information technology as a factor of production: the role of differences among firms, Economics of Innovation and New Technology 3: 183-200. https://doi.org/10.1080/10438599500000002

Central Statistical Bureau of Latvia. 2019a. Table ISG040: Area, population density and population (at the beginning of the year and average) in regions, cities under state jurisdiction and counties, Statistical database. Retrieved from https://www.csb.gov.lv/en/statistics/statistics-by-theme/population/number-and-change/tables/isg040/area-population-density-andpopulation

Central Statistical Bureau of Latvia. 2019b. Table IKG10_110: Gross domestic product by statistical region and city (at current prices), Statistical database. Retrieved from https://www.csb.gov.lv/en/statistics/statistics-by-theme/economy/gdp/tables/ikg10_110/grossdomestic-product-statistical-region-and-city-current

Central Statistical Bureau of Latvia. 2019c. Table DSG060: Average monthly gross wages and salaries in statistical regions by kind of activity (in euro), Statistical database. Retrieved from https://www.csb.gov.lv/en/statistics/statistics-by-theme/socialconditions/wages/tables/dsg060/average-monthly-gross-wages-and-salaries

Central Statistical Bureau of Latvia. 2019d. Table NBG083: Employed by economic activity (NACE Rev. 2.) and statistical region, Statistical database. Retrieved from https://www.csb.gov.lv/en/statistics/statistics-by-theme/socialconditions/unemployment/tables/nbg083/employed-economic-activity-nace-rev-2-and

Central Statistical Bureau of Latvia. 2019e. Table IVG040: Non-financial investment by statistical region (at constant prices of 2017, mln euro), Statistical database. Retrieved from https://www.csb.gov.lv/en/statistics/statistics-by-theme/economy/investments/tables/ivg040/nonfinancial-investment-statistical-region-constant 
INSIGHTS INTO REGIONAL DEVELOPMENT

ISSN 2669-0195 (online) http://jssidoi.org/jesi/

2020 Volume 2 Number 2 (June)

http://doi.org/10.9770/IRD.2020.2.2(4)

Cocalia, A. 2015. Knowledge and information - new factors of production in the context of globalization, Ecoforum 1(4): 119-124.

Cusolito, A.; Maloney, W. 2018. Productivity Revisited. Shifting Paradigms in Analysis and Policy.

International Bank for Reconstruction and Development, The World Bank.

https://doi.org/10.1596/978-1-4648-1334-4

Daft, R. 2009. Management. 9th edition. Cengage Learning.

Drucker, P. 1977. An Introductionary View of Management. New York, USA: Harperís College Press.

Egorova, T. 2014. Словарь иностранных слов современного русского языка. [The Dictionary of Foreign Words in the Modern Russian Language]. Moscow, Russia: Adelant.

Evans, W.; Siegel, I. 1942. The meaning of productivity indexes, Journal of the American Statistical Association 37(217): $103-111$. https://doi.org/10.1080/01621459.1942.10500619

Fujita, M.; Krugman, P.; Venables, A. 1999. The Spatial Economy: Cities, Regions, and International Trade. Cambridge, MA, UK: MIT Press.

Granberg, A. 2004. Основы региональной экономики. [Guidelines of Regional Economics]. Moscow, Russia: Publishing House of the Higher School of Economics.

Helmane, I. 2017. Zemā uzņēmumu produktivitāte radīs draudus attīstībai nākotnē. [Low efficiency of enterprises will threat the future development]. LV portal. Retrieved from https://lvportals.lv/norises/290814-zema-uznemumu-produktivitate-radis-draudus-attistibai$\underline{\text { nakotne-2017 }}$

H.M. Treasury. 2001. The Regional Dimension, Productivity in the UK (3). Retrieved from www.hm-treasury.gov.uk/5427.htm

INSEAD (The Business School for the World); the Adecco Group; \& Tata Communications. 2019. The Global Talent Competitiveness Index 2019: Entrepreneurial Talent and Global Competitiveness. Lanvin, B.; Monteiro, F. (Eds.). France: Fontainebleau.

International Monetary Fund. 2019. World Economic Outlook 2019: Global Manufacturing Downturn, Rising Trade Barriers. Retrieved from https://www.imf.org/en/Publications/WEO/Issues/2019/10/01/world-economic-outlook-october-2019

Jekabsone, S.; Skribane, I. 2018. Produktivitātes slazds. [Trap of Efficiency]. Retrieved from https://www.db.lv/zinas/produktivitates$\underline{\text { slazds-478227 }}$

Korshenkov, E.; Ignatyev S.; Dembovskiy, V. 2019. Теоретическое и методологическое обоснование изучения производительности и продуктивности в региональной экономике [Theoretical and methodological framework of the investigation of productivity and efficiency in the regional economics], Social Sciences Bulletin 2(29): 25-64.

Krasnopyorovs, O. 2012. Latvijas ekonomikas izaugsmi noteicošie faktori. [Factors Determining Growth of Latvian Economy]. Doctoral Thesis. Riga, Latvia: University of Latvia.

Krugman, P. 1991a. Geography and Trade. Cambridge, Massachusetts, London, UK: MIT Press.

Krugman, P. 1991b. Increasing returns and economic geography, Journal of Political Economy 99: 483-499.

https://doi.org/10.1086/261763

Krugman, P. 1997. The Age of Diminished Expectations. U.S. Economic Policy in the 1990s. 3rd edition. Cambridge, Massachusetts, London, UK: MIT Press.

Kurakov, L. (Ed.). 2017. Микроэкономика. [Microeconomics]. Moscow, Russia: Publishing House of the IAEP.

Mankiw, G.; Romer, D.; Weil, D. 1992. A contribution to the empirics of economic growth, Quarterly Journal of Economics 2(107): 407437. https://doi.org/10.3386/w3541

Marshall, A. 1890. Principles of Economics. London, UK: Macmillan and Co. 


\section{INSIGHTS INTO REGIONAL DEVELOPMENT}

ISSN 2669-0195 (online) http://jssidoi.org/jesi/

2020 Volume 2 Number 2 (June)

http://doi.org/10.9770/IRD.2020.2.2(4)

Nechet, F.; Melo, P.; Graham, D. 2012. Transportation-induced agglomeration effects and productivity of firms in MegaCity Region of Paris Basin, Transportation Research Record Journal of the Transportation Research Board 1(2307): 21-30. https://doi.org/10.3141/2307$\underline{03}$

Neef, D. 2003. The Economic Impact of Knowledge. Boston, USA: Butterworth-Heinemann.

New Zealand Institute of Economic Research. 2014. Regional economies: shape, performance and drivers, NZIER Public Discussion Paper, Working Paper 2014/03. Retrieved from https://nzier.org.nz/static/media/filer_public/e4/1f/e41f5c81-2d63-4548-8859-

2dad5c8e213f/nzier_public_discussion_document_2014-03-regional_economies.pdf

Radeva, I. 2014. Synergy evaluation in economic clusters: approaches and solutions, International Workshop on Advanced Control and Optimization: Step Ahead - ACOSA, Bankya, Bulgaria. Retrieved from https://www.researchgate.net/publication/324013367 SYNERGY EVALUATION IN ECONOMIC CLUSTERS APPROCHES AND $\underline{\text { SOLUTIONS }}$

Rice, P.; Venables, A. 2004a. Productivity: Understanding Regional Differences. Retrieved from http://cep.lse.ac.uk/pubs/download/CP162.pdf

Rice, P.; Venables, A. 2004b. Spatial determinants of productivity: analysis for the regions of Great Britain, CEP Discussion Paper 642. Retrieved from http://cep.lse.ac.uk/pubs/download/dp0642.pdf

Romer, P. 1989a. Capital accumulation in the theory of long run growth, in Barro, R. (Ed.). Modern Business Cycle Theory. Cambridge, MA: Harvard University Press, 51-127.

Romer, P. 1989b. Human capital and growth: theory and evidence, NBER Working Paper 3173. Retrieved from https://www.nber.org/papers/w3173.pdf

Sala-i-Martín, X.; Baller, S.; Crotti, R.; Di Battista, A.; Drzeniek, M.; Geiger, T.; Gomez, G.; Marti, G. 2016. Competitiveness agendas to reignite growth: findings from the Global Competitiveness Index, in World Economic Forum. The Global Competitiveness Report 20162017. Schwab, K. (Ed.). Geneva: World Economic Forum, 3-50.

Samuelson, P.; Nordhaus, W. 2010. Economics. 19th edition. McGraw-Hill/Irwin.

Selivanova-Fyodorova, N.; Komarova, V.; Lonska, J.; Mietule, I. 2019. Differentiation of internal regions in the EU countries, Insights into Regional Development 1(4): 370-384. https://doi.org/10.9770/ird.2019.1.4(7)

Shteinbuka, I. (Ed.). 2019. Produktivitātes celšana: tendences un nākotnes izaicinājumi. [Increase of Efficiency: Tendencies and Future Challenges]. Riga, Latvia: Academic Publishing House of the University of Latvia.

Simpson, S. 2014. Macroeconomics: Economic Performance and Growth. Retrieved from http://www.investopedia.com/university/macroeconomics/macroeconomics9.asp

Solow, R. 1956. A contribution to the theory of economic growth, Quarterly Journal of Economics LXX: 65-94.

Stack, L. 2016. Doing the Right Things Right: How the Effective Executive Spends Time. Oakland, CA: Berrett-Koehler Publishers.

Stankevics, A. 2014. Augstākās izglītības loma reǵiona veiktspējas paaugstināšanā. [The Role of Higher Education in the Increase of Performance of a Region]. Doctoral Thesis. Daugavpils, Latvia: Daugavpils University.

Stankevics, A.; Ignatjeva, S.; Mensikovs, V. 2014. Higher education's contribution to economic performance and innovativeness in Latvia: exploratory research, Economic Annals 59(202): 7-41.

Stepinya, I. 2019. Produktivitāte: kāpēc būtiska Latvijai un Latvijas uzṇēmējiem? [Efficiency: why is important for Latvia and Latvia's entrepreneurs?] Shteinbuka I. (Ed.). Produktivitātes celšana: tendences un nākotnes izaicinājumi. [Increase of Efficiency: Tendencies and Future Challenges]. Riga, Latvia: Academic Publishing House of the University of Latvia, 159-172.

Taube, А. 1966. Русско-английский словарь: около 30000 слов. [Russian-English Dictionary: about 30000 words]. 2nd edition. Moscow: Soviet Encyclopedia. 
INSIGHTS INTO REGIONAL DEVELOPMENT

ISSN 2669-0195 (online) http://jssidoi.org/jesi/

2020 Volume 2 Number 2 (June)

http://doi.org/10.9770/IRD.2020.2.2(4)

Ullman, E. 1958. Regional development and the geography of concentration, Papers and Proceedings of the Regional Science Association 4: 179-198. https://doi.org/10.1111/j.14355597.1958.tb01629.x

Volkov, Y. 2004. Регионоведение. [Regional Studies]. Rostov-on-Don, Russia: FENIKS.

World Economic Forum. 2016. The Global Competitiveness Report 2016-2017. Schwab K. (Ed.). Geneva, Switzerland: World Economic Forum.

World Economic Forum. 2018. The Global Competitiveness Report 2018. Schwab K. (Ed.). Geneva, Switzerland: World Economic Forum.

Zeibote, Z. 2018. Klasteri kā reǵionālo politiku un konkurētspēju ietekmējošs faktors.[Clusters as a Factor Influencing Regional Policy and Competitiveness]. Doctoral Thesis. Riga, Latvia: Baltic International Academy.

Zemitis, M. 2019. Eiropas Komisijas ziṇojums par Latviju: Produktivitātes reǵionālā dimensija. [European Commission’s Report about Latvia: Regional Dimension of Efficiency]. Riga, Latvia: European Commission's Council in Latvia.

Zenovich, Е. 1998. Словарь иностранных слов и выражений. [The Dictionary of Foreign Words and Phrases]. Moscow: Olymp, Publishing House AST.

Zhdanova, I. (Ed.). 1995. Англо-русский экономический словарь. [English-Russian Economic Dictionary]. Moscow: Russian Language.

Evgeniy KORSHENKOV is the Master of Economics, the Doctoral student in "Regional Economics and Economic Policy" of Baltic International Academy, Latvia. His work experience is connected with banking sector and local municipality. Currently he is the member of the board of local public transport company. Research interests: sustainable regional development; productivity, efficiency and effectiveness; transport and its infrastructure.

ORCID ID: orcid.org/0000-0002-3758-0980

Sergey IGNATYEV is the Doctor of Economics, the Associate Professor of Baltic International Academy, Latvia. He is currently teaching international marketing and strategic management. Research interests: entrepreneurship and regional development; marketing of territories; small business internationalization; sustainability.

ORCID ID: orcid.org/0000-0002-3815-6874

Copyright (C) 2020 by author(s) and VsI Entrepreneurship and Sustainability Center

This work is licensed under the Creative Commons Attribution International License (CC BY).

http://creativecommons.org/licenses/by/4.0/

(c) (i) Open Access 